\title{
TYPOLOGIA ROSYJSKO-POLSKICH BŁĘDÓW JĘZYKOWYCH DZIECKA DWUJĘZYCZNEGO
}

\author{
RADOSŁAW KALETA \\ Uniwersytet Warszawski \\ Wydział Lingwistyki Stosowanej \\ Katedra Białorutenistyki \\ Pracownia Glottodydaktyki Białorutenistycznej \\ ul. Szturmowa 4, 02-678 Warszawa, Polska \\ e-mail: rkaleta@uw.edu.pl \\ (nadesłano 7.09.2017; zaakceptowano 21.10.2017)
}

Z dedykacją dla Marysi (Maszy)

\section{Abstract \\ Typology of Russian-Polish language errors of a bilingual child}

The article presents a typology of errors made by a bilingual (Russian-Polish) girl, mostly in Polish, but also in Russian. The typology is divided into interference errors (from the second mother tongue) and errors caused by insufficient knowledge of the language system (caused by various reasons) both in Polish and Russian. Lapsological analysis showed some analogies with errors made by foreigners as well as PolishRussian interlingual analogies.

\section{Key words}

Russian, Polish, language error, linguistic analogy, interference, child's language, mother tongue, bilingualism. 


\section{Abstrakt}

W artykule przedstawiono typologię błędów dwujęzycznej (rosyjsko-polskiej) dziewczynki, popełnianych głównie w języku polskim, choć także rosyjskim. W typologii uwzględniono błędy interferencyjne ( $\mathrm{z}$ drugiego języka ojczystego/macierzystego) oraz błędy spowodowane nieopanowaniem (z różnych przyczyn) systemu zarówno języka polskiego, jak i rosyjskiego. Analiza wykazała pewne analogie lapsologiczne $\mathrm{w}$ porównaniu z błędami cudzoziemskimi oraz szereg analogii międzyjęzykowych polsko-rosyjskich.

\section{Słowa kluczowe}

Język rosyjski, język polski, błąd językowy, analogia lapsologiczna, interferencja, język dziecka, język ojczysty/macierzysty, dwujęzyczność rodzinna.

Błędy to droga do prawdy

Fiodor Dostojewski

Błędy człowieka czynia go sympatycznym Johann Wolfgang von Goethe

Niniejszy artykuł stanowi kontynuację badań prowadzonych przez autora w ramach Pracowni Glottodydaktyki Białorutenistycznej Uniwersytetu Warszawskiego. Wcześniejsze prace ${ }^{1}$ dotyczyły błędów młodych dorosłych uczących się jednego z języków słowiańskich jako obcego i nie obejmowały zagadnień związanych z przyswajaniem języków przez dzieci dwujęzyczne. Jednakże analizowanie procesu uczenia się języków ojczystych/macierzystych przez dzieci dwujęzyczne wskazuje na występowanie (obok szeregu różnic) wielu procesów analogicznych do tych, jakie towarzyszą nauce języka ojczystego przez osoby jednojęzyczne, czy przy nauce języka obcego, na co wskazuje popełnianie podobnych błędów.

$\mathrm{W}$ artykule używamy terminu bład językowy, który rozumiemy jako odstępstwo od normy (zarówno wzorcowej, jak i użytkowej). Popularny termin błą glottodydaktyczny jest dość specyficzny, węższy (jako odstępstwo od normy glottodydaktycznej) i może budzić pewne kontrowersje ${ }^{2}$, a dla nas oznacza z jednej strony błąd uczącego się języka obcego, a z drugiej strony mógłby być rozumiany jako błąd nauczyciela (np. błąd metodyczny), który przecież także jest elementem układu glottodydaktycznego ${ }^{3}$.

\footnotetext{
1 Np. R. Kaleta. Polsko-białoruska lapsologia glottodydaktyczna. Warszawa: Katedra Białorutenistyki. Wydział Lingwistyki Stosowanej. Uniwersytet Warszawski, 2015.

2 Zob. A. Dąbrowska, M. Pasieka. Błąd językowy - co to takiego? Rozważania o błędzie językowym $w$ glottodydaktyce polonistycznej. „Acta Universitatis Lodziensis. Kształcenie Polonistyczne Cudzoziemców" 2015, t. 22, s. 25-26.

3 Więcej o układach glottodydaktycznych zob. P.E. Gębal. Glottodydaktyka porównawcza jako nowa subdyscyplina glottodydaktyki. „Lingwistyka Stosowana” 2014, t. 10, s. 39-42.
} 
Przedstawiona niżej typologia błędów opracowana została na podstawie materiału zasłyszanego i zebranego z wypowiedzi dziewczynki (Marysi/Maszy) pochodzącej z rosyjsko-polskiej rodziny mieszkającej w Polsce, choć nierzadko podróżującej do Rosji, w okresie od 2. do 4. roku jej życia ${ }^{4}$. W domu dominuje język rosyjski (jako język matki, język dziadków kontaktujących się przez Skype’a, język nauki i zabawy domowej), czyli de facto język mniejszości ${ }^{5}$. Język polski jest językiem otoczenia, przedszkola i (rzadszych niż z matką) kontaktów z ojcem, ale de facto językiem większości, bo dziecko mieszka na stałe w Polsce. Marysia (Masza) w badanym okresie dobrze znosiła przełączanie kodów między językiem domu a językiem otoczenia zewnętrznego, jednak gorzej tolerowała dwujęzyczność w samym domu, czyli rozmowy rodziców, w których każdy z nich mówił w swoim języku, także z dzieckiem. Powodowało to, że dziecko nie tylko przełączało się z języka na język w ramach rozmów z jednym $z$ rodziców, lecz także używało na przemian różnych kodów w jednej wypowiedzi (by wyrazić myśl przy użyciu najszybciej dostępnych w danej chwili środków językowych, a czasem po prostu dla zabawy $)^{6}$, co z jednej strony jest zjawiskiem naturalnym i normalnym, a z drugiej strony niezbyt korzystnym, gdyż tworzy rodzaj języka trzeciego - hybrydowego, mieszanego polsko-rosyjskiego. Taki rodzaj języka może być zabawny, stanowi element rozwoju, ale bywa rozumiany i dobrze odbierany niemal wyłącznie w środowisku domowym, które go rozumie. Środowisko zewnętrzne (częściej rówieśnicze niż dorosłe) takiego mieszanego języka nie musi jednak (choć w pewnych sytacjach może) ani rozumieć, ani tolerować, co często nie jest łatwe do przyjęcia dla dwujęzycznego dziecka, które w którymś momencie postawi sobie pytanie o własną tożsamość i przynależność, skoro w Polsce nie jest do końca Polakiem (jego polszczyzna zawiera przecież wiele rusycyzmów), a w Rosji - do końca Rosjaninem (jego język rosyjski może być nawet w miarę poprawny, ale z bardziej lub mniej wyczuwalnym polskim akcentem i polską intonacją). Być może dlatego niejednokrotnie można było zaobserwować chęć dziecka do ujednolicenia języka domu, wyrażaną w prośbach (czasem na krótko spełnianych) do ojca, by - jak matka - posługiwał się językiem rosyjskim. Z jednej strony prośba taka może być czystym dziecięcym kaprysem czy chęcią wygody (lenistwem językowym?), a z drugiej strony może wynikać także z poczucia braku jasno zdefiniowanych obszarów używania w domu każdego z języków, czyli momentami niekonsekwentnej/płynnej strategii wychowania językowego. Zarówno ojciec, jak i matka rozmawiają $\mathrm{z}$ dzieckiem we własnym języku (zgodnie ze strategią one person, one language 'jedna osoba, jeden język') ${ }^{7}$, ale między sobą rozmawiają już bardzo róż-

4 Celowo do badań błędów językowych wybrano dziewczynkę, gdyż dziewczynki w tym wieku mają na ogół bogatszy słownik niż chłopcy, którzy rozwijają się wolniej, czego jednak nie można wyolbrzymiać, gdyż wielką rolę u dzieci odgrywają też czynniki indywidualne. Średnio zasób słów dziecka pomiędzy 2. a 3. rokiem życia wynosi od kilkudziesięciu do kilkuset wyrazów; zob. T. Rożek. Słownik wyrazów obcych. „Gość Niedzielny”, nr 26, z dn. 2 lipca 2017, s. 58-59.

5 Por. K. Wróblewska-Pawlak. Naturalna dwujęzyczność, czyli o dwujęzycznym wychowaniu dzieci. „Języki Obce w Szkole” 2013, nr 1, s. 91.

6 Więcej o przełączaniu kodów u dzieci zob. M. Velísnká. Family bilingualism. Charles University in Prague. Faculty of Education. Department of English Language and Literature. Supervisor: Paed Dr Marie Hofmannová. Prague 2007, s. 31-32.

7 Tamże, s. 20; K. Wróblewska-Pawlak. Naturalna dwujęzyczność..., s. 93 i nast. 
nie (także przy dziecku): niekiedy w swoim języku, raz po polsku, raz po rosyjsku, czasem też z przełączaniem kodów w połowie zdania, co może być źródłem zamieszania dla dziecka, a także pewnym wzorem do naśladowania.

W takim kontekście funkcjonowania w najbliższym środowisku domowym zarówno języka polskiego (języka większości zewnętrznej/państwowej), jak i języka rosyjskiego (języka mniejszości wewnętrznej/domowej) nie dziwią silne naturalne procesy nakładania się obu języków w kształtującym się dopiero języku dziecka, na co wskazują błędy analizowane w niniejszym artykule. W zebranym materiale skupiono się raczej na błędach w języku polskim - języku większościowym, języku kraju, w którym dziecko mieszka. W przypadku badanego dziecka dwujęzycznego przeważają błędy interferencyjne. W wypunktowanych wypowiedziach dziecka i w komentarzach do nich odnotowano w sumie 220 przykładów błędów (w tym dziewięć błędów analogicznych), z czego najliczniejszą grupę stanowią błędy leksykalne (jest ich w sumie 71). Kwestia opracowania typologii błędów dziecka dwujęzycznego nie jest sprawą oczywistą. Nasuwa się pytanie, czy stosować klasyfikacje dotyczące błędów w języku ojczystym, czy klasyfikacje błędów nierodzimych użytkowników języka ${ }^{8}$. W opracowaniach rosyjskich można spotkać pogląd, że dziecko, które od urodzenia poznawało świat w języku rosyjskim i komunikowało się po rosyjsku choćby tylko z jednym z rodziców, popełnia błędy charakterystyczne dla rodzimych użytkowników tego języka ${ }^{9}$. Rzadziej

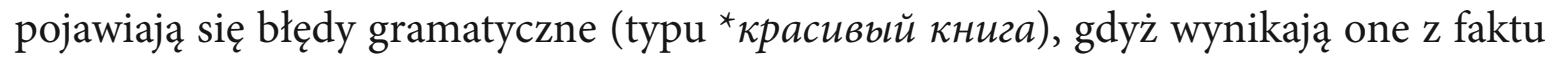
nieznajomości danej leksyki, rzadsze są błędy z zakresu łączliwości i fleksji ${ }^{10}$. Być może powyższe twierdzenie sprawdza się w przypadku dzieci chodzących do szkoły, gdyż w naszych badaniach odnotowano błędy charakterystyczne dla cudzoziemców i dziecięcych, a nie dorosłych rodzimych użytkowników języka. W przypadku wybranego do badań dziecka dwujęzycznego rodzi się pytanie, czy językiem ojczystym jest (zgodnie z polską nazwą) język (polski) ojca, czy język (rosyjski) matki (język macierzysty zgodnie $\mathrm{z}$ angielską nomenklaturą, ang. mother tongue). Trudno byłoby jednak określić, który $\mathrm{z}$ nich jest silniejszy ${ }^{11}$, gdyż oba $\mathrm{z}$ założenia mają być językami ojczystymi/ macierzystymi, pytanie tylko, czy można mieć dwa języki ojczyste/macierzyste i na ile jest to możliwe w praktyce, czy jeden $\mathrm{z}$ nich nie będzie jednak w jakimś stopniu pierwszym, a inny drugim (bo tak się to mimo wszystko numeruje w literaturze), czy (w tym konkretnym przypadku) rosyjski nie stanie się językiem jedynie odziedziczonym (utraconym). Nawet jeśli oba języki są w jakiejś mierze ojczystymi/macierzystymi, to zapewne im dziecko będzie starsze, tym większy wpływ będzie miał na nie język otoczenia zewnętrznego, ale w przypadku dziecka trzyletniego wpływ języka wewnętrzego/domowego (matki) ma jeszcze na tyle duże znaczenie, że oba języki mogą znajdować się na porównywalnym poziomie „ojczystości/macierzystości”, gdyż w obu dziecko może reagować emocjonalnie, skarżyć się, szukać wsparcia rodzica, zadawać

\footnotetext{
8 Więcej o istniejących klasyfikacjach zob. A. Dąbrowska, M. Pasieka. Błąd językowy - co to takiego?..., s. 27-31.

9 Е.А. Хамраева. Русский язык для детей-билингвов: теория и практика. Учебное пособие. Москва: Билингва, 2015, s. 93.

10 Tamże.

11 Por. M. Velísnká. Family bilingualism..., s. 22.
} 
mu pytania ${ }^{12}$. Mamy tu zatem do czynienia $\mathrm{z}$ tzw. dwujęzycznością dziecięcą (ang. infant bilingualism, fr. bilinguisme de lenfant), naturalną (ang. natural/primary bilingualism, fr. bilinguisme naturel) lub rodzinną (fr. bilinguisme familial), zrównoważoną (ang. balanced bilingualism), charakterystyczną dla rodzin dwujęzycznych, w których dzieci od początku uczą się od swoich rodziców dwóch języków (ang. simultaneous bilingualism, fr. bilingualié d'enfance précoce simultanée) ${ }^{13}$.

W przypadku dziecka dwujęzycznego rosyjsko-polskiego możemy stosować jednocześnie w zależności od materii błędu typologie lapsologiczne odnoszące się zarówno do języka ojczystego, jak i do języka obcego w zależności od materii błędu. U takiego dziecka wyróżniamy zatem następujące błędy ze względu na mechanizm ich powstawania:

1) błędy w języku polskim:

a) spowodowane interferencją z języka rosyjskiego, np. Tu jest ${ }^{\star}$ princ (książę);

b) spowodowane niedostatecznym opanowaniem systemu (czego przyczyn może być wiele, np. generalizacja, interferencja wewnątrzjęzykowa, a także przyczyny pozajęzykowe, jak wiek, różne stopnie uzdolnienia itd. $\left.{ }^{14}\right)$, np. sklep dla ${ }^{\star} d z i e c i o ́ w$; Tam nie było wszystkich *dzieciów (dzieci);

2) błędy w języku rosyjskim:

a) spowodowane interferencją z języka polskiego, np. $Я{ }^{{ }^{*}}$ памыла (почистила) зyбbl;

b) spowodowane niedostatecznym opanowaniem systemu, np. ${ }^{\star}$ бежу (бегу).

Odrębną kategorię (o której tu siłą rzeczy zaledwie wspomnimy) mogłyby stanowić błędy celowe, tj. głównie błędy leksykalne, polegające na stosowaniu dla zabawy raz polskiego, raz rosyjskiego wyrazu. Ustalenie jednak, czy w danym momencie zostało to spowodowane interferencją, czy celową zabawą, jest bardzo trudne. Do pewnych wniosków można dojść (naturalnie bez stuprocentowej pewności), odczytując kontekst sytuacyjny oraz dzięki dobrej znajomości zachowań dziecka.

W lingwistycznej analizie błędy najczęściej opisuje się z punktu widzenia systemów języka i na tym opiera się także typologia lapsologiczna zaprezentowana w niniejszym artykule. Ponieważ błędy zostały wyekscerpowane z wypowiedzi dwujęzycznej dziewczynki między 2. i 4. rokiem życia, siłą rzeczy mogły być one tylko zasłyszane, stąd na potrzeby artykułu dokonano ich rekonstrukcji na piśmie, z użyciem transkrypcji fonetycznej tam tylko, gdzie było to naszym zdaniem konieczne. Błędy oznaczono gwiazdką, a poprawną formę przytoczono w nawiasie.

\section{A1. Błędy w języku polskim spowodowane interferencją języka rosyjskiego A1.1. Błędy fonetyczne}

\section{A1.1.1. Błędne zmiękczanie spółgłosek}

*[kon'efka] ([konefka $])$

\footnotetext{
12 Por. Е.А. Хамраева. Русский язык для детей-билингвов..., s. 8.

13 M. Velísnká. Family bilingualism..., s. 11-13. Terminologię francuską zob. K. Wróblewska-Pawlak. Naturalna dwujęzyczność..., s. 90.

14 Poglądy różnych specjalistów na ten temat zob. R. Kaleta. Dyskusja nad błędem językowym w wybranych polskich pracach językoznawczych wydanych w latach 1978-2008 (przeglad). „Lingwistyka Stosowana" 2009, t. 1, s. 167 i nast.
} 


\section{A1.2. Błędy fleksyjne}

\section{A1.2.1. Błędna odmiana zaimków przeczących}

$Z$ kim rozmawiasz? - ${ }^{\star}$ Nie z kim (Z nikim);

Za kogo chcesz się pomodlić? - ${ }^{\star} \mathrm{Ni} \mathrm{za}$ kogo (Za nikogo);

Nie możesz się ${ }^{\star}$ ni w co (w nic) angażować.

\section{A1.2.2. Błędna końcówka fleksyjna}

Chleb bez ${ }^{\star}$ mioda (miodu);

Ciocia nie dała ${ }^{\star}$ Grzesiu (Grzesiowi) żadnego ${ }^{*}$ lista (listu);

Dam prezent ${ }^{\star}$ Jasiu (Jasiowi) ${ }^{\star}$ Dawidu (Dawidowi);

Kocham *tatu (tatę);

wiaderko $z^{*}$ łopatkiej (łopatką);

po ${ }^{\star}$ lasu (lesie);

*jabłki [japki] (jabłka);

*Polaki (Polacy) nie mówią po rosyjsku;

Kiedy przyjadą * gości (goście)?;

Pokarmić *kaczuszek (kaczuszki);

Zobaczyliśmy *rybek, krabów (rybki, kraby);

On będzie *smutnyj (smutny).

\section{A1.2.3. Błędne unieruchomienie fleksyjne}

(zwrot do misia) Zobacz ${ }^{\star}$ Uszatek! (Uszatku!).

\section{A1.2.4. Błędne przypisanie rodzaju gramatycznego lub liczby}

Daj mi *sałat (sałatę) $)^{15}$, ros. салаm (r. męski);

${ }^{\star}$ Fontan (fontanna), ros. фонтан (r. męski);

*Drugi skarpetek (druga skarpetka), ros. второй носок (r. męski);

To *jest (są) drzwi, ros. дверь (lp., r. żeński).

\section{A1.2.5. Błędna odmiana czasownika}

Kaczuszki *jadą (jedzą);

Ale *będzie pomieszać (pomieszam/będę mieszać);

Pociąg ^będzie ułożyć (będę układać).

\section{A1.2.6. Nierozróżnianie rodzajów: męsko- i niemęskoosobowego}

Grzyby? Gdzie *oni (one) są?

Ja podchodziłam do dzieci i ${ }^{\star}$ oni brali (one brały) cukierki.

\section{A1.2.7. Błędne formy zaimków osobowych}

Trzymam *jego (go).

15 Nauczenie dziecka uprzejmości i używania proszę (Daj mi, proszę, sałatę) i odróżnienia normy wzorcowej/wysokiej od użytkowej jest kwestią kultury słowa i wychowania. W zależności od przyjętych kryteriów można by zatem było mówić w tym przypadku również o błędzie pragamtycznym. 


\section{A1.3. Błędy składniowe}

\section{A1.3.1. Błędna rekcja czasownika}

${ }^{*}$ Ciebie czekałam (Na ciebie czekałam);

Mama $\mathrm{z}$ nami pojedzie ${ }^{\star}$ na pociągu (pociągiem);

Widziałeś, jak przyjechał ${ }^{\star}$ na samochodzie? (samochodem);

Kiedy lecieliśmy ${ }^{*}$ na samolocie (samolotem), to też szybko lecieliśmy;

Zadzwonię * ci (do ciebie);

Nie lubię * gorącą kaszę (gorącej kaszy);

Nie umyliśmy ${ }^{\star}$ zęby (zębów);

Nie założyłam *skarpetkę (skarpetki).

\section{A1.3.2. Błędne konstrukcje składniowe}

${ }^{\star} \mathrm{U}$ mnie nie ma kataru (Nie mam kataru);

*U mnie jest większa choinka (Mam większą choinkę);

${ }^{*}$ U nas jest kasza (Mamy/jemy kasze));

${ }^{\star} \mathrm{U}$ mnie jest obiad (Mam/jem obiad);

${ }^{\star} \mathrm{U}$ ciebie jest tort (Masz tort);

*U ciebie jest fajna broda (Masz fajną brodę);

${ }^{\star}$ U mnie boli brzuch (Mnie boli brzuch);

${ }^{*}$ Mnie podoba się (Lubię) zbierać grzyby;

${ }^{\star}$ Mnie podoba się (Lubię), jak ty mnie kąpiesz.

\section{A1.3.3. Błędna rekcja liczebnika}

Dwa *doma (domy);

Mam dwa *talerzyka (talerzyki);

Ja chcę dwa ${ }^{\star}$ misia (misie);

Zjadła dwa ${ }^{*}$ cukierka (cukierki);

Poproszę trzy ${ }^{*}$ chrupka (chrupki);

${ }^{\star}$ Jest dwa lasa (Są dwa lasy).

\section{A1.3.4. Błędny przyimek}

Zawsze zaczynamy ${ }^{\star} \mathrm{z}$ (od) piosenki, dobrze?;

Jedziemy ${ }^{\star} w$ cerkiew (do cerkwi).

\section{A1.4. Błędy leksykalne}

\section{A1.4.1. Kalkowanie słów}

Błędy tego typu dotyczą kalkowania słów (w tym homonimów międzyjęzykowych) należących do różnych części mowy, najczęściej rzeczowników, czasowników, ale też przymiotników, przyimków czy zaimków.

${ }^{\star}$ Kto to (ktoś) płacze;

${ }^{\star}$ Pośle (po) pracy;

Chyba ${ }^{*}$ wsio (wszystko);

Zobacz, ${ }^{*}$ skolko (ile) piasku;

One nie są ${ }^{*}$ skolskie (śliskie);

Tu są okna ${ }^{*}$ krugłe (okrągłe);

Słoń, lew, małpa, *begiemot (hipopotam);

To jest ${ }^{*}$ markowka (marchewka); 
Samochód bez ${ }^{\star}$ kaliosów (kó);

To jest od * pakupek (zakupów);

Rajstopy są w ${ }^{*}$ pałoski (paski);

Tu jest * princ (książę), a tam księżniczka;

$Z^{*}$ papą (tatą);

Jaki ${ }^{\star}$ malczik (chłopiec);

Wykopał `jamę (dół);

$\mathrm{W}$ tej grze nie ma ${ }^{*}$ człowieka (ludzika);

Gdzie ja mogę *sieśt'? (usiąść);

Mamo, *odziewaj się (ubieraj się);

*Odziewamy (Ubieramy) się;

${ }^{\star}$ Skazałam (Powiedziałam);

${ }^{\star}$ Ty skazałaś (Powiedziałaś);

*Ustałam (Zmęczyłam) się;

${ }^{*}$ Guliałam (Spacerowałam);

*Prygłam (Skoczyłam);

*Prygałam na batucie (Skakałam na trampolinie/batucie);

Chcesz ${ }^{\star}$ uwidzieć? (zobaczyć);

*Podwiń (Przesuń) się;

${ }^{\star}$ Podwiń/Przedwiń (Przesuń) to tu;

Wszystkie kwiatki * podniały (podniosły) się;

Ciemno *stało (się zrobiło);

To ${ }^{\star}$ zaredziło się (Naładowało);

Czemu ty * pośmiejałeś (zaśmiałeś) się?;

${ }^{\star}$ Musiałeś (Powinieneś był) to zrobić;

Miś może siedzieć $\mathrm{i}{ }^{\star}$ stojać (stać);

Kasza *ostyła (ostygła);

${ }^{*}$ Dumałam (Myślałam), że nie ma mojej pasty;

${ }^{\star}$ Poniuchaj (Powąchaj), jak pięknie pachnie;

Nie mogłam sama *odkryć dźwier (otworzyć drzwi);

Jakie masz fajne ${ }^{*}$ oczki (okulary) ${ }^{16}$;

*Ubierz (Zabierz) rękę/krzesło;

${ }^{\star}$ Ubieramy (Sprzątamy) to?;

Ja coś powiedziałam * drugiego (innego);

*Papa da drugą wiłkę (Tata da inny widelec);

${ }^{*}$ Drugi raz (Innym razem) pójdę z tobą;

To jest ${ }^{*}$ deska (tablica) dla dzieci;

Pociąg ${ }^{\star}$ złamał się (zepsuł się);

16 Ten i kolejne przykłady wynikają z homonimii międzyjęzykowej, por. R. Kaleta. O polsko-białorusko-rosyjskiej homonimii międzyjęzykowej w ujęciu glottodydaktycznym. [W:] Wokót homonimii międzyjęzykowej. Red. M. Majewska. Warszawa: Wydawnictwo UKSW (w druku); zob. też: I. Kozielewski. Słownik wyrazów o podobnym brzmieniu a odmiennym znaczeniu w języku rosyjskim i polskim. Warszawa: Państwowe Zakłady Wydawnictw Szkolnych, 1959; K. Kusal Rosyjsko-polski słownik homonimów międzyjęzykowych. Wrocław: Wydawnictwo Uniwersytetu Wrocławskiego, 2002; B. Gasek Лексико-семантическая интерференция в процессе перевода (на материале русского и польского языков). Wrocław: Wydawnictwo Uniwersytetu Wrocławskiego 2012. 
*Złamało się (Zepsuło się);

Położyłam daleko, żeby nie *dostał (dosięgną);

Ja kredki * dostałam (wyjęłam);

Mamo, ja cię *lubię (kocham);

Gdzie wypluć tę *kostkę (pestkę)?;

Gotuję *owoce (warzywa);

Usiadła na *swój stół (swoje krzesło);

Już nie będziemy się * grać (bawić).

Tam był wielki basen $z^{\star}$ górkami (zjeżdzalniami).

\section{A1.4.2. Nadawanie zwrotności czasownikom niezwrotnym}

Zostało *się (Zostało);

Został *się (Został);

Została ${ }^{\star}$ się (Została) tylko jedna kartka;

Chcę zostać * się (zostać) tu.

\section{A1.5. Błędy słowotwórcze}

${ }^{*}$ Tosin brat (brat Tosi) tam jest;

Ty będziesz czytać, a ja będę *podmuwiać (podpowiadać).

\section{A.1.6. Błędy złożone}

Do grupy tej zaliczamy wypowiedzi zawierające więcej niż jeden rodzaj błędu ${ }^{17}$, na przykład:

na *bałkonu (balkonie) - błąd fonetyczny ([ł] zamiast [1]) i błąd fleksyjny;

Kiedy wróciłam z przedszkola, jeszcze *się zostali (zostały) cukierki - błąd leksykalny (nadanie zwrotności czasownikowi) i błąd fleksyjny (nierozróżnianie rodzaju męsko- i niemęskoosobowego);

Ja nie idę *spotkać mamę (Ja nie idę po mamę) - błąd fleksyjny (mamy) i leksykalny (spotkać to kalka ros. встретumь);

Dwa * plecaka nie zmieszczą się na *spinie (Dwa plecaki nie zmieszczą się plecach) - błąd składniowy (rekcja liczebnika) i błąd leksykalny (kalka rosyjska);

$\mathrm{Nie}^{\star}$ znam, jak w to się ${ }^{\star}$ graje (Nie wiem, jak w to się gra) - błąd leksykalny i błąd fleksyjny;

^Ty mnie zrobił to łóżko (To ty zrobiłeś dla mnie to łóżko) - błąd składniowy i błąd fleksyjny czasownika);

Mój tatuś *samy ukochany i samy piękny (jest najukochańszy i najpiękniejszy) - błąd składniowy (elipsa czasownika być) i 2 błędy słowotwórcze przymiotnika;

${ }^{\star}$ Drugie dzieci bez samochodów poszli i oni zmokli (Inne dzieci nie pojechały samochodami i zmokły) - błąd leksykalny, 2 błędy fleksyjne, błąd składniowy (nadużywanie zaimka osobowego), błąd logiczno-językowy ( ${ }^{*}$ pójść z samochodem);

*ja czekam ciebie (czekam na ciebie) - 2 błędy składniowe (nadużywanie zaimka osobowego i rekcja czasownika);

${ }^{\star} U$ Asi urodziny jest (Asia ma urodziny) - 2 błędy składniowe (kalka konstrukcji składniowej oraz błąd szyku);

Zobacz, jaką mam *czapeczkę do basejnu (czepek na basen) - błąd leksykalny i błąd fleksyjny.

17 Por. A. Dąbrowska. Składniowa konstrukcja dysmorficzna jako błąd kompleksowy. „Poradnik Językowy" 2012, nr 6, s. 82-93. 


\section{A2. Błędy w języku polskim spowodowane niedostatecznym opanowaniem systemu}

\section{A2.1. Błędy fleksyjne}

Błędy fleksyjne sprowadzają się najczęściej do nieprawidłowej odmiany rzeczowników i czasowników, spowodowanej m.in. hipergeneralizacją czy nierozróżnianiem rodzaju żeńskiego i męskiego. Są charakterystyczne dla dzieci w procesie rozwoju języka.

Czy panie nosza krawaty? - Nie, tylko * pany (panowie);

Możesz umyć * ząby (zęby);

do *nogów (nóg) i *ręk (rąk);

Mam dużo * siłów ( sił);

Nie ma oknów (okien);

Sama malowałam * pieseka (psa/pieska);

Budujemy ${ }^{\star}$ samolota (samolot);

$\mathrm{z}^{\star}$ babciem $\mathrm{i}^{\star}$ dziadką ( $\mathrm{z}$ babcią i dziadkiem);

z babcią i ${ }^{*}$ dziadką ( $\mathrm{z}$ babcią i dziadkiem);

On chce iść $z^{\star}$ kolegiem (kolegą);

babcia ${ }^{\star}{ }^{\star}$ dziadka (dziadek);

*moja syra (mój ser);

Dużo *jedzeniów (jedzenia);

*dla ludź (ludzi);

sklep dla ${ }^{\star}$ dzieciów (dzieci);

Tam nie było wszystkich ${ }^{\star}$ dzieciów (dzieci);

Ja ci * powiedzę (powiem);

Ja ci ${ }^{\star}$ wybierzę (wybiorę);

On tam * weszedł (wszedł);

Tata ${ }^{\star}$ dała (dał), ${ }^{\star}$ patrzyła (patrzył), ${ }^{\star}$ myła (mył);

Tata, ty *sama (sam);

Tata, ${ }^{\star}$ usiadłaś? (usiadłeś);

Kto *dała (dał);

moja mama, ${ }^{\star}$ moja (mój) tata;

Są ${ }^{*}$ dwa/dwie (Jest dwoje) drzwi.

\section{A2.2. Błędy składniowe}

Błędy składniowe dotyczyły głównie skomplikowanej konstrukcji zdań celowych oraz szyku (ostatni przykład).

Chcę, ${ }^{\star}$ żeby ty odkleiłeś (żebyś ty odkleił);

*Żeby ja nie płakałam (żebym ja nie płakała);

A ja chciałam, ${ }^{\star}$ żeby ty ze mną pojechałeś (żebyś ze mną pojechał);

${ }^{\star}$ Nie tam idź (Nie idź tam).

\section{A2.3. Błędy leksykalne}

Błędy leksykalne polegały zazwyczaj na błędnym wyborze aspektu czasownika oraz nienadawaniu zwrotności czasownikom zwrotnym.

Trzeba rozłożyć makaron - Za chwilę będziemy * rozłożyć (rozkładać);

Kiedy mama przyjdzie? Bo już nie mogę ${ }^{\star}$ doczekać (się doczekać).

\section{A2.4. Błędy złożone}

Przyniosę swoją książkę do *farbów (kolorowania) - błąd fleksyjny i leksykalny. 
Na zakończenie omawiania błędów w języku polskim warto wspomnieć także o wypowiedziach zawierających błędy złożone mieszane, czyli wynikające zarówno z interferencji (omówione w części A1), jak i z niewystarczającego opanowania systemu (omówione w części A2), na przykład:

Nie chcę, 'żeby jego trzymałeś (żebyś go trzymał) - interferencyjny błąd fleksyjny zaimka i błąd składniowy;

Chciałam, ${ }^{*}$ żeby ty mnie przyniesiesz (żebyś mi przyniósł) jakąś niespodziankę - interferencyjny błąd fleksyjny zaimka i błąd składniowy;

*Ja chciała, żeby już przyjechałeś (Chciałam, żebyś już przyjechał) - interferencyjny błąd fleksyjny czasownika i błąd składniowy;

Kiedy chodziłam * do basejna (na basen) - błąd składniowy i interferencyjny błąd fleksyjny.

\title{
B1. Błędy w języku rosyjskim spowodowane interferencją języka polskiego
}

\section{B1.1. Błędy fleksyjne}

*Приглашам (Приглашаю) в гости;

Мой папа красиво *одеты (одетый);

Кто не закрыл ${ }^{*}$ фломастера (фломастер);

Я хочу * печеньке (печеньку).

\section{B1.2. Błędy składniowe}

Я не пойду * по нево (за ним);

Не вижу ${ }^{\star}$ дедули (дедулю);

Почему он это ест? - Потому что ^любит (ему нравится).

\section{B1.3. Błędy leksykalne}

*Пильную его (Слежу/Смотрю за ним);

Папа *мувит (говорит) по-польски;

Как ты чувствуешь *се (себя чувствуешь)?;

Я сама ${ }^{\star}$ наложу (положу) на тарелку;

Я * памыла (почистила) зубы;

*Помою (почищу) зубки.

\section{B2. Błędy w języku rosyjskim spowodowane niedostatecznym opanowaniem sys- temu}

\author{
B2.1. Błędy fleksyjne

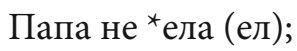 \\ *бежу (бегу); \\ Давид меня *подвигивает (подвигает); \\ Давай *побегем (побежим) вместе; \\ Для *детих (детей).
}

\section{B2.1. Błędy złożone}

*У Греты 4 *лет (Грете 4 года) - błąd składniowy i fleksyjny.

Kwestia stworzenia typologii lapsologicznej rosyjsko-polskiego dziecka dwujęzycznego nie jest oczywista i stwarza niemało komplikacji. Czasem trudno zdecydować, czy zastosowane [gul’ałam] jest błędem fleksyjnym w języku rosyjskim (zamiast 
Я гуляла), czy kalką leksykalną w języku polskim (zamiast Spacerowałam). Zdawałoby się, że pomóc mogłoby ustalenie, w jakim języku zwracał się do dziecka dorosły. Jeśli więc dorosły powiedział po rosyjsku Можешь добавить i usłyszał odpowiedź dziecka [dabaw'iłam] (zamiast $Я$ добавила), to (w myśl strategii one person, one language) można byłoby wywnioskować, że jest to interferencyjny błąd fleksyjny w języku rosyjskim. Jeśli rodzic powiedział po polsku Kupiłem płyn i usłyszał odpowiedź-pytanie [ty kup'ił?] (zamiast Kupiłeś?), to można zakładać, że jest to analogiczny interferencyjny błąd fleksyjny w języku polskim. Pewności, że nie była to jednak odpowiedź w języku rosyjskim, nie ma i być nie może. Kwestię ewentualnych jednoznacznych rozstrzygnięć komplikuje fakt, że dziecko nie zawsze konsekwentnie odpowiada w języku rodzica, gdyż ma świadomość, że rodzic rozumie oba języki, często więc odpowiada w drugim języku ojczystym/macierzystym, często z błędem interferencyjnym, np. na rosyjski komunikat dorosłego: Люблю тебя, dziecko odpowiedziało: Ja też *lubię cię (zamiast Ja też cię kocham). W rozstrzyganiu mógłby pozornie pomóc sam początek zdania, np. Już dajełam, co sugerowałoby błąd w języku polskim. Jednak i takie założenie wydaje się z góry fałszywe, gdyż język dziecka nie jest bynajmniej konsekwentny, na co wskazują wypowiedzi złożone na przemian ze słów polskich i rosyjskich, np. ${ }^{\star}$ Princesy takie ${ }^{\star} j u b k i{ }^{\star}$ majut (zamiast Księżczniczki maja takie spódnice), które można uznać za błędne w języku polskim (2 błędy leksykalne i błąd fleksyjny) albo w języku rosyjskim (2 błędy fleksyjne) Princesy ${ }^{\star}$ takie jubki ${ }^{*}$ majut (zamiast Принцесы такие юбки имеют), do czego można by jeszcze dodać błąd składniowy, bo zdecydowanie lepiej po rosyjsku brzmiałoby: У принцесс такие юбки. Inny przykład stanowi wykrzyknik Moja papa!. Może on być rozpatrywany dwojako: z jednej strony uznać go można za błąd w użyciu zaimka w języku rosyjskim (моя zamiast мой), z drugiej natomiast jako błąd w rodzaju zaimka i równocześnie błąd leksykalny w języku polskim $\left({ }^{\star}\right.$ Moja papa zamiast ${ }^{\star}$ Mój tata).

Warto też wspomnieć o możliwym błędzie natury pragmatycznej czy kulturowej, występującym w polskich wypowiedziach typu Daj mi wiadro. Zdanie takie potraktować można jako niegrzeczne, zwłaszcza jeśli podkreśla to ton wypowiedzi, ale jeśli zdanie zostało wypowiedziane dość spokojnie, to i sens wypowiedzi jest raczej neutralny. Uprzejmości przydaje w tym wypadku użycie proszę (Daj mi, proszę, wiadro), które jest standartem wypowiedzi wzorcowej wobec osób starszych czy nieznanych lub wobec tych, którym pragniemy okazać szacunek i uprzejmość, ale w kontaktach z rówieśnikami praktyka bywa różna. To też kwestia kultury języka i wychowania. W języku rosyjskim wypowiedź analogiczna bez nожалуйста uchodzi za bardzo niegrzeczną. Dla równowagi wychowaczej dziecka dwujęzycznego wersja wzorcowa (uprzejma) powinna być używana także w zdaniach polskich.

$\mathrm{Na}$ zakończenie warto byłoby zaznaczyć, że $\mathrm{w}$ analizowanym materiale dostrzec można pewne analogie (procesy analogiczne) lapsologiczne skutkujące pojawieniem się błędów analogicznych ${ }^{18}$, do których możemy zaliczyć:

18 Por. R. Kaleta. Glottodydaktyczne błędy analogiczne na przykładzie języka polskiego i języka białoruskiego. „Acta Universitatis Lodziensis. Kształcenie Polonistyczne Cudzoziemców” 2015, t. 22, s. 319-335. 
błędy analogiczne do błędów cudzoziemców, tzn. takie, jakie nierzadko popełniają dorośli cudzoziemcy uczący się języka polskiego ${ }^{19} \mathrm{i}$ rosyjskiego ${ }^{20}$ (lub innych języków pokrewnych $\left.{ }^{21}\right), 6$ przykładów, np. ${ }^{*}$ Fontan (fontanna); Kaczuszki ${ }^{*} j a d a$ (jedza); Ale ${ }^{\star} b e ̨-$ dzie pomieszać (pomieszam/będę mieszać); On chce iść $z$ *kolegiem (kolega); He вuњy ^дедули (дедулю); Я * памыла (почистила) зубы;

błędy analogiczne międzyjęzykowe (ten sam typ błędu dotyczący tej samej materii w obu językach, można je odnotować także wśród błędów cudzoziemskich) ${ }^{22}$, trzy przykłady, np. On będzie *smutnyj (smutny) vs. Mой nana красиво ${ }^{\star}$ oдеты (oдеm); Nie założytam ${ }^{*}$ skarpetke (skarpetki) vs. Не вижу ${ }^{\star}$ дедули (дедулю); ${ }^{*}$ Mnie podoba się (Lubię) zbierać grzyby vs. Почему он это ест? - Потому что ^любит (ему нравитcr).

Badania nad procesami i błędami analogicznymi warto pogłębiać na różnych płaszczyznach:

1) u dzieci dwujęzycznych (między ich językami ojczystymi/macierzystymi oraz w porównaniu z błędami rodzimych użytkowników języka oraz błędami obcokrajowców);

2) u obcokrajowców uczących się języków obcych (zwłaszcza blisko spokrewniony$\mathrm{ch})^{23}$

3) u obcokrajowców w porównaniu z rodzimymi użytkownikami języka ${ }^{24}$.

Wyniki takich badań z pewnością zainteresowałyby nie tylko lingwistów, glottodydaktyków, metodyków i psychologów.

19 Por. M. Foland-Kugler. Uczymy polskiego na Wschodzie. Poradnik metodyczny. Warszawa: Wydawnictwa CODN, 1998; A. Dąbrowska, U. Dobesz, M. Pasieka. Co warto wiedzieć. Poradnik metodyczny dla nauczycieli języka polskiego jako obcego na Wschodzie. Warszawa: Ośrodek Rozwoju Edukacji, 2010; R. Kaleta. Polsko-białoruska lapsologia...

20 Por. Z. Harczuk. Interferencja języka polskiego w procesie nauczania języka rosyjskiego. Warszawa: Państwowe Zakłady Wydawnictw Szkolnych, 1972; B. Wewiór. Błędy gramatyczne i leksykalne. [W:] Z problematyki błędów obcojęzycznych. Red. F. Grucza. Warszawa: Wydawnictwa Szkolne i Pedagogiczne, 1978; J. Korzeniewska-Rogalewicz. Błą leksykalny a dydaktyka jezzyka obcego. Na materiale jezzyka rosyjskiego. Warszawa: Wydawnictwa Uniwersytetu Warszawskiego, 1986; J. Gliwińska-Kotynia. Najczęstsze błędy Polaków uczących się języka rosyjskiego. [W:] Bogactwo językowe i kulturowe Europy w oczach Polaków i cudzoziemców. Red. M. Biernacka i M. Wojenka-Karasek. Łódź: Piktor, 2011, s. 210-216.

21 Por. R. Kaleta. Glottodydaktyczne błędy analogiczne...

22 Por. tamże.

23 Por. tamże.

$24 \mathrm{Na}$ przykład błędy polskich maturzystów rozwiązujących testy certyfikatowe na poziomie C2. Zob. G. Przechodzka, W. Miodunka. Kompetencja językowa polskich maturzystów. Na podstawie testów certyfikatowych $z$ języka polskiego jako obcego na poziomie zaawansowanym C2. Analiza jakościowa. „Polonistyka” 2006, nr 8, s. 6-17; zob. też: A. Dąbrowska, M. Pasieka. Błąd językowy - co to takiego? ..., s. 31 . 


\section{Bibliografia}

Dąbrowska A., Dobesz U., Pasieka M. Co warto wiedzieć. Poradnik metodyczny dla nauczycieli języka polskiego jako obcego na Wschodzie. Warszawa: Ośrodek Rozwoju Edukacji, 2010.

Dąbrowska A. Składniowa konstrukcja dysmorficzna jako błąd kompleksowy. „Poradnik Językowy” 2012, nr 6, s. 82-93.

Dąbrowska A., Pasieka M. Błąd językowy - co to takiego? Rozważania o błędzie językowym w glottodydaktyce polonistycznej. „Acta Universitatis Lodziensis. Kształcenie Polonistyczne Cudzoziemców" 2015, t. 22, s. 25-26.

Foland-Kugler M. Uczymy polskiego na Wschodzie. Poradnik metodyczny. Warszawa: Wydawnictwa CODN, 1998.

Gasek B. Лексико-семантическая интерференция в процессе перевода (на материале русского u польского языков). Wrocław: Wydawnictwo Uniwersytetu Wrocławskiego 2012.

Gliwińska-Kotynia J. Najczęstsze błędy Polaków uczących się języka rosyjskiego. [W:] Bogactwo językowe i kulturowe Europy w oczach Polaków i cudzoziemców. Red. M. Biernacka i M. Wojenka-Karasek. Łódź: Piktor, 2011, s. 210-216.

Harczuk Z. Interferencja języka polskiego w procesie nauczania języka rosyjskiego. Warszawa: Państwowe Zakłady Wydawnictw Szkolnych, 1972.

Kaleta R. Polsko-białoruska lapsologia glottodydaktyczna. Warszawa: Katedra Katedra Białorutenistyki. Wydział Lingwistyki Stosowanej. Uniwersytet Warszawski, 2015.

Gębal P.E. Glottodydaktyka porównawcza jako nowa subdyscyplina glottodydaktyki. „Lingwistyka Stosowana" 2014, t. 10, s. 39-42.

Kaleta R. Dyskusja nad błędem językowym w wybranych polskich pracach językoznawczych wydanych w latach 1978-2008 (przeglą). „Lingwistyka Stosowana” 2009, t. 1, s. 151-171.

Kaleta R. Glottodydaktyczne błędy analogiczne na przykładzie języka polskiego i języka białoruskiego. „Acta Universitatis Lodziensis. Kształcenie Polonistyczne Cudzoziemców” 2015, t. 22, s. 319-335.

Kaleta R. Polsko-białoruska lapsologia glottodydaktyczna. Warszawa: Katedra Katedra Białorutenistyki. Wydział Lingwistyki Stosowanej. Uniwersytet Warszawski, 2015.

Kaleta R. O polsko-białorusko-rosyjskiej homonimii międzyjęzykowej w ujęciu glottodydaktycznym. [W:] Wokót homonimii międzyjęzykowej. Red. M. Majewska. Warszawa: Wydawnictwo UKSW, 2017 (w druku).

Korzeniewska-Rogalewicz J. Bład leksykalny a dydaktyka języka obcego. Na materiale języka rosyjskiego. Warszawa: Wydawnictwa Uniwersytetu Warszawskiego, 1986.

Kozielewski I. Słownik wyrazów o podobnym brzmieniu a odmiennym znaczeniu w języku rosyjskim i polskim. Warszawa: Państwowe Zakłady Wydawnictw Szkolnych, 1959.

Kusal K. Rosyjsko-polski słownik homonimów międzyjęzykowych. Wrocław: Wydawnictwo Uniwersytetu Wrocławskiego, 2002.

Przechodzka G., Miodunka W. Kompetencja językowa polskich maturzystów. Na podstawie testów certyfikatowych z języka polskiego jako obcego na poziomie zaawansowanym C2. Analiza jakościowa. „Polonistyka” 2006, nr 8, s. 6-17.

Rożek T. Słownik wyrazów obcych. „Gość Niedzielny”, nr 26, z dn. 2 lipca 2017, s. 58-59.

Velísnká M. Family bilingualism. Charles University in Prague. Faculty of Education. Department of English Language and Literature. Supervisor: Paed Dr Marie Hofmannová. Prague 2007. [Online:] <https://dspace.cuni.cz/bitstream/handle/20.500.11956/9282/DPTX_2010_1_11410_ OSZD001_69289_0_22217.pdf?sequence=1> (dostęp: 20.08.2017).

Wewiór B. Błędy gramatyczne i leksykalne. [W:] Z problematyki błędów obcojęzycznych. Red. F. Grucza. Warszawa: Wydawnictwa Szkolne i Pedagogiczne, 1978. 
Wróblewska-Pawlak K. Naturalna dwujęzyczność, czyli o dwujęzycznym wychowaniu dzieci. „Języki Obce w Szkole" 2013, nr 1, s. 88-97.

Хамраева Е.А. Русский язык для детей-билингвов: теория и практика. Учебное пособие. Москва: Билингва, 2015. 